\title{
Survey on After-class Business English Reading and Construction of Self-access Reading Model Guided by CBI
}

\author{
Zhao Shurong \\ School of Foreign Languages, Shandong Women's University P. R. China
}

\begin{abstract}
Comparing to general English reading, lesson of Business English reading involves specific teaching aims and principles. By investigating the after-class reading of business English majors and collecting relative data, this paper analyzes the amount of, attitude toward, purposes of and barriers to Business English reading, and summarizes the major problems. To solve the problems, a new CBI guided self-access after-class reading mode is put forward.
\end{abstract}

KEYWORD: Business English; After-class reading; CBI; Self-access after-class reading model

\section{INTRODUCTION}

Coupled with the trend of globalization, English for Specific Purposes (ESP) has become an international phenomenon [1]. Business English, as the most important branch of ESP, has attracted widespread concern. In 2012, Business English got formally listed in the newly-revised specialty catalogue of China, and went on track of fast development. On the other hand, the study and research of Business English lags far behind of its rapid expansion in size and number of students. Researchers have not yet reached consensus in many important aspects, especially in the study and research on characteristics of business English lesson and of business English learners. Various problems arose in the practice of business English teaching, which calls for further study and exploration.

\section{BUSINESS ENGLISH READING VS. GENERAL ENGLISH READING}

Business English reading, as one of the core subject for business English major, plays a dominant role in the improvement of language skill, acquisition of business knowledge, and development of communication capability under the business circumstance. It shares a lot in common with general English reading, and should follow the recognized teaching norm and law in the English reading field. While at the same time, it retains distinguished characteristics comparing with general English reading. The difference lies first in the principle of "needs priority". In the designing of business English curriculum, great emphasis was put on the learners' needs, and the content of and methods of teaching usually center on the kinds of and characteristics of language skill of learners' future job circumstance. Hutchinson \& Waters [2] argued that needs analysis was the most remarkable trait of ESP curriculum design. Another trait of business English is shown in the principle of "content based instruction". The integration of business knowledge and English language distinguishes business English from general English. So, as what was written by Robinson [3], although language teaching is the important task and aim of all language lessons, ESP lessons should not just stop there, and realizing a specific target by using language is the ultimate teaching aim of ESP.

Because of the special teaching aim and principles of business English, it becomes practically important to study the teaching characteristics of business English reading. Business English teachers are supposed to pay efforts in learning business English, researching its characteristics, exploring its law of teaching, getting to know the special needs of learners and hence adopting appropriate teaching methods. In order to explore the real characteristics, the author carried out an investigation on the afterclass business English reading of business English major students. In this field, previous investigation was made by Li ruifang [4], Zhang fake [5], while their research was mainly on general English reading. Few researches were carried out especially on business English. This thesis, investigates the learners' reading aim, reading strategy, reading 
difficulties, and then raises suggestions accordingly on business English reading guidance.

\section{METHODOLOGY}

\subsection{Purpose of study.}

The purpose of this study is to obtain detailed information about the after-class business English reading, summarize the characteristics and tell the difference between general English reading and business English reading.

\subsection{Instruments.}

This study adopts the methods combining qualitative and quantitative approach. First, 10 students were chosen in random and were interviewed on their after-class business English reading, hence offering reference for the designing of questionnaire. Second, the questionnaire was formulated, taking Duan zili's [6] questionnaires made previously. A pre-test was carried out, the result of which was used to revise the questionnaire. The questionnaire covers 6 parts, including the personal information of participants, the self-assessment on general English reading proficiency (reading speed and ability) and business English proficiency, attitude towards business English reading (reading purpose and interest), reading strategy of Business English (briefed as BE hereinafter) reading, length of time devoted to $\mathrm{BE}$ reading, Genres, sources of getting reading materials and reading difficulty. Likert scale, single selection and multiple choices were adopted in answering different items.

\subsection{Participants.}

155 students of business English major in grade 2 or 3 were chosen as objects of this study. There's not marked difference in their English proficiency and they all have studied related subjects like Business English reading, international trade theory and practice, which provided them with firsthand experience in business English reading. 153 effective questionnaires were obtained out of 155 paper issuance.

\section{DATA ANALYSIS}

The data was input into and analyzed by SPSS 17.0. For part 2 of the questionnaire, we compared the self-assessment of General English (briefed as GE hereinafter) reading proficiency and BE proficiency with the method of Paired samples T-test. Frequency analysis was carried out on the rest of the items.

\subsection{Self-assessment on $B E$ reading}

This part of the survey contains 4 items, requiring the participants to assess respectively their $\mathrm{BE}$ reading ability, GE reading ability, BE reading speed and GE speed. The answers take the form of Likert scale, with 1 for very bad/ very slow, and 5 for very good/ very fast. The two pairs of items were analyzed by paired samples T test using SPSS 17.0, to test if there's marked difference. The test showed that there's remarkable difference between the selfassessment on BE reading ability and GE reading ability $(\mathrm{t}=-10.02$, df $=152, \mathrm{p}<0.05)$, and the selfassessment on BE reading ability is remarkably lower than that on GE reading ability, which is showed in table 1. Similar findings were got on selfassessment on reading speed $(\mathrm{t}=-9.29, \mathrm{df}=152, \mathrm{p}<$ 0.05). Interview also shows that most students are lack of confidence on their BE reading. They think that $\mathrm{BE}$ reading is too difficult for them, which involves complicated background knowledge, and the comprehension of individual words usually does not lead to understanding of the sentences. They gradually lost confidence after meeting such frustrations. This phenomenon may result from various factors. Ellis and Johnson ${ }^{[7]}$ held that BE learners fall into 2 categories: job-experienced learners and pre-experienced ones. College students obviously belong to the latter. They are lack of experience about the business world, and it's impossible for them to be familiar with every business field under the wide concept of business. Furthermore, learners haven't got used to BE reading, of which most are authentic materials because of long experience of GE reading, which is mostly a kind of simulated reading, with revised and simplified materials. Another reason may be that learners began their BE reading from start of college life, much later than GE reading.

Table 1 Self-assessment on BE reading and GE reading

\begin{tabular}{|c|c|c|c|c|c|}
\hline \multirow{2}{*}{ reading ability } & \multicolumn{2}{|c|}{$\mathrm{BE}$} & \multicolumn{2}{c|}{$\mathrm{GE}$} & \multirow{2}{*}{$\mathrm{T}(152)$} \\
\cline { 2 - 6 } & $\mathrm{M}$ & $\mathrm{SD}$ & $\mathrm{M}$ & $\mathrm{SD}$ & \\
\cline { 2 - 6 } & 2.97 & 0.54 & 3.52 & 0.59 & $-10.02 *$ \\
\hline reading speed & 2.78 & 0.59 & 3.37 & 0.66 & $-9.29 *$ \\
\hline
\end{tabular}

$* \mathrm{p}<0.05$

\subsection{Attitude towards BE reading}

There are 3 items on the attitude towards BE reading, including "the help of $\mathrm{BE}$ reading to my language ability", "interest on BE reading", in Likert scale, and "my purpose of BE reading", which is a multiple choice item. The descriptive analysis shows that most learners have recognized the significance of $\mathrm{BE}$ reading on their language proficiency and business knowledge acquisition. But on the other 
hand, their interest on BE reading differentiates with each other (Std. Deviation=1.01), and the average value is not high $(\mathrm{M}=2.73)$. The conflicting attitude toward BE reading may result from various factors. Ying huilan [8] carried out a survey on "the students-centered reading material choosing", which showed that $58.4 \%$ students held that the reading material influenced reading most. For Business English reading, the authentic material, with great extent of difficulty, covering wide scope of business knowledge, dents interest greatly.

As to purpose of reading, analysis shows that the most frequently referred to purposes cover acquiring business knowledge (30.4\%), improving language proficiency $(29.8 \%)$ and broadening vision $(23.1 \%)$. In the interview, the purpose of preparing for future job hunting was also mentioned by several students. The various purposes of reading, being one of the most important subjective factor in reading, brings along different reading strategy, discourse strategy and reading result. Dupis and Askov [9] classified the reading purposes into 3 categories, including functional reading, occupational reading and entertaining reading. The survey showed that for BE reading most students read for functional purposes, and the purpose of entertainment was hardly mentioned.

\subsection{Time devoted to, material choice of and difficulty involved in $B E$ reading}

Time devoted to $\mathrm{BE}$ reading. Descriptive analysis shows that $55.6 \%$ students only spent 10 minutes to one hour per week in BE reading, 32.7\% students spent one to three hours. The time spent in BE reading turns to be far from adequacy to develop fluent readers. Regarding to previous study on reading, researchers have reached consensus on the significance of extensive reading on enhancement of language proficiency. Day and Bamford [10] pointed out that the best method of learning a foreign language, besides being immersed in the language circumstance, is to read extensively articles of target language. Therefore for business English teachers, it's essentially important to find specific ways in inspiring students to read extensively after class.

\subsection{Sources of reading materials and genres.}

According to the data collected, the most frequently mentioned sources are textbook $(47.8 \%)$, internet $(24.3 \%)$ and library (22.7\%). It seems that students read mainly textbook articles after class, which is also an evidence of insufficiency in reading. As to the genres of reading materials, the survey showed that a wide variety of genres were covered, as what is shown by table 2 .
Table 2 Genres of BE reading (Frequencies)

\begin{tabular}{|l|c|c|}
\hline genre & $\mathrm{N}$ & Percent \\
\hline Textbook & 116 & $26.5 \%$ \\
\hline Economic news & 88 & $20.1 \%$ \\
\hline Company profile & 40 & $9.1 \%$ \\
\hline Business comment & 35 & $8.0 \%$ \\
\hline Business report & 22 & $5.0 \%$ \\
\hline Business letters & 36 & $8.2 \%$ \\
\hline Contracts & 13 & $3.0 \%$ \\
\hline Advertisements & 54 & $12.3 \%$ \\
\hline Business books & 34 & $7.8 \%$ \\
\hline Total & 438 & $100 \%$ \\
\hline
\end{tabular}

\subsection{Barriers to $B E$ reading}

For the item of reading barriers, the data collected shows that "specialized terms ranks first, and lack of business knowledge the second, followed by lack of background knowledge, long and complicated sentences, and semantic style.

For the item "the kind of help from the teacher you need most", "recommending reading material" tops the list $(\mathrm{n}=79,52.7 \%)$, followed by "offering guidance in reading strategy and methods" $(n=57$, $55.3 \%)$, and "supervision and encouragement" $(\mathrm{n}=27$, $79.4 \%)$.

\section{CONCLUSION}

Characteristics and problems of $\mathrm{BE}$ reading. To summarize the data mentioned above, characteristics and problems can be concluded as follows. (1) Attitude: learners have recognized the positive influence of $\mathrm{BE}$ reading on improvement of their language ability, while they are lack of confidence when reading $\mathrm{BE}$ materials, showing much lower self-assessment in their BE reading ability and speed than in GE ability and speed. (2) Purposes of reading: most of the purposes of reading can be classified as functional, few as entertaining. (3) Amount of reading: the amount of and time devoted to $\mathrm{BE}$ reading are far less than that of GE, far from enough in cultivating fluent reader. (4) Reading materials: they cover a wide scope in genres and in business fields, and internet and library are learners' major source of searching for reading material. (5) Reading barriers: high degree of difficulty, low interest and helpless in material choice.

Self-access reading model guided by CBI. Regarding the characteristics and problems mentioned above, it's suggested to construct selfaccess reading model guided by CBI. CBI, known as content-based instruction, attracts wide attention of researchers, especially in the field of ESP. It focuses 
on the integration and interaction of language skill training and specialized knowledge teaching, targeting combination of knowledge construction, thinking training and language skill improvement [11]. Grabe [12] holds that CBI takes content as vehicle of language acquisition and lays basis for meaningful language input. Lili [13] proved through teaching experiment that the application of CBI in $\mathrm{BE}$ teaching improved both learners' language ability and learning attitude, and functioned specially in arousing interest. Therefore, the principle of CBI just hits the nail on the head in meeting the difficulty of $\mathrm{BE}$ reading and the application can be feasible and of practical meaning. The self-access reading model guided by CBI may cover the following major points. (1) Target setting: dominant acquisition of business knowledge+ recessive improvement of language skill+ cultivation of critical thinking. (2) Material choosing: the premise is to select authentic material, on the basis of which may conduct recommendation of material in different grades of difficulty and different topics. (3) Self-access reading: it's to encourage learners to develop their pace of reading, experience the real enjoyment of reading and the charm of fantastic business. (4) Reading feedback: it's to ask learners to write down their experience, exchange their idea through reading logs and reading report.

$\mathrm{BE}$ reading retains marked characteristics. The teaching target will be missed and learners needs will not be met, if teachers only adopt the existed teaching principles and teaching mode. Therefore, it's advisable it carry out further practical study on the CBI guided reading guidance mode.

\section{REFERENCES}

[1] Belcher, D. D. 2006. English for specific purposes: Teaching to perceived needs and imagined futures in worlds of work, study, and everyday life. TESOL Quarterly, 40, 133-156.

[2] Hutchinson. T. \& Waters. A. 1987. English for specific purposes. Cambridge University Press: 3, 63.

[3] Robinson. P. C. 1980. ESP (English for Specific Purposes): the present position. Oxford: Pergamon Press: 6-8

[4] Li ruifang, Zhang ying, Cheng musheng, 2004, Survey of non-English majors in Tsinghua University on their after class reading. Foreign Language World (2): 35-40.

[5] Zhang fake, Zhao ting, 2007. Survey on nonlinguistic reading barriers and construction of extracurricular reading model. Foreign Language World (6): 74-79.

[6] Duan zili, 2006. Survey on strategies used by Business English students in after-class reading and reactive autonomy. Foreign Language World (3): 19-23.

[7] Ellis, M. \& Johnson. C. 2002. Teaching business English: an introduction to business English for language teachers, trainers, and course organizers. Oxford University Press: 15-18.

[8] Ying huilan, Xu huifang, 2011. Learner-centeredmode of choosing reading material. Foreign Language Teaching and Research (3): 206-209.

[9] Dupuis, M. \& M. Askov, E. N. 1982. Content area reading: an individualized approach. Prentice-Hall.

[10] Day, R. \& Bamford, J. 1998. Extensive reading in the second language classroom. Cambridge: Cambridge University Press.

[11] Sun youzhong, Li liwen, 2011. CBI, ESPand the trend of development of English major and college English reform in china. Foreign Languages Research (5):1-4.

[12] Grabe. W. \& Stoller. F. L. 2002. Teaching and researching: Reading. Pearson education.

[13] Li li, 2010. A Study on Effects of Applying CBI to Business English Teaching. Journal Beijing International Studies University (8):74-79. 